\title{
A Primer on Exporting to Mexico ${ }^{1}$
}

\author{
Christina D. Storz, Timothy G. Taylor, and Gary F. Fairchild ${ }^{2}$
}

\section{Introduction}

Every year the U.S. Department of State publishes extensive Country Commercial Guides for a large number of countries. These guides provide a great deal of information useful to individuals interested in developing export markets either through direct exports or through direct foreign investment. This paper provides an abridged version of the Country Commercial Guide for Mexico as well as supplemental information of direct relevance to agribusiness firms. It is hoped that the information contained in this report provides a useful starting point for individuals interested in exploring export or investment opportunities in Mexico.

Note: County Commercial Guides are available for U.S. exporters from the National Trade Data Bank's CD-ROM or via the Internet. Please contact Stat-USA by telephone (1-800) STAT-USA for more information. Country Commercial Guides can be accessed via the World Wide Web at http://www.stat-usa.gov, http://www.state.gov, and http://www.mac.doc.gov. They can also be ordered as a hard copy or on diskette from the National Technical Information Service (NTIS) by telephone (1-800) 553-NTIS. American exporters seeking general export information/assistance and country-specific commercial information should contact the U.S. Department of Commerce, Trade Information Center by telephone (1-800) USA-TRADE; or by fax (202) 482-4473.

\section{Economic and Political Overview}

The most outstanding feature of our bilateral relationship in the past decade has been the North American Free Trade Agreement (NAFTA), which created a free trade zone for Mexico, the United States, and Canada. Since the enactment of NAFTA in January of 1994, Mexico's imports from the United States have grown exponentially, totaling US\$98 billion in 2002. The U.S. share of Mexico's trade has likewise increased with NAFTA, accounting for nearly $78 \%$ of Mexico's total trade in 2002. Mexico is now the second most important U.S. trading partner after Canada. American exports to Mexico are greater than U.S. exports to the rest of Latin America combined.

The Mexican economy, after facing a recession and negative $0.3 \%$ real growth in 2001, showed positive growth of $0.9 \%$ in 2002. As Mexico is inextricably linked with the United States, the extent of Mexico's recovery will depend on U.S. economic performance. The Mexican Ministry of Finance

1. This is EDIS document FE517, a publication of the Department of Food and Resource Economics, Florida Cooperative Extension Service, Institute of Food and Agricultural Sciences, University of Florida, Gainesville, FL. Published February 2005. Please visit the EDIS website at http://edis.ifas.ufl.edu.

2. Christina D. Storz, Research Assistant; Timothy G. Taylor, Professor; and Gary F. Fairchild, Professor, Department of Food and Resource Economics, Florida Cooperative Extension Service, Institute of Food and Agricultural Sciences, University of Florida, Gainesville, FL. 
estimates that Mexico will undergo a $2.3 \%$ growth rate in 2003 .

On a year-over-year basis, the peso has depreciated over $7 \%$ to 10.50 pesos per U.S. dollar. However, the weaker peso has not caused a significant macroeconomic disturbance. The first two quarters of 2003 experienced an inflation rate of $1.25 \%$. During the month of June of 2003, the rate of inflation was a mere $0.08 \%$, the lowest inflation rate since 1969.

Unfortunately, the political climate for structural change is uncertain. In 2003, the Institutional Revolutionary Party (PRI) gained relative majority (holding 245 of 500 seats). This may lead to gridlock with Fox's National Action Party (PAN) Administration, which only holds 157 seats in Congress. A contentious political environment has thwarted progress on electricity and labor sector reforms. If Fox is unable to obtain the legislative support that he needs, these reforms will not progress, which translates into fewer jobs and less economic growth. For example, the electrical reform could increase foreign investment in Mexico by US $\$ 5$ billion per year. Despite less public income, the government of Mexico has maintained fiscal prudence through expenditure cuts and the privatization of state assets, which should limit the increase in the government's debt. Such prudence has buttressed investor confidence.

Given the more than $\$ 98$ billion in U.S. exports in 2002, U.S. companies in industries across the board should consider their market potential in Mexico. The Embassy's U.S. Commercial Service offices in Mexico and the Agricultural Trade Office offer a variety of programs to assist U.S. companies to identify and meet with potential agents and distributors, assess market potential, and avoid problems. American firms contemplating business in Mexico are encouraged to call these offices for advice and assistance.

NAFTA continues to boost trade between the three member countries and improve Mexico's overall economic standing. Since the enactment of NAFTA in 1994, Mexico's exports have increased by over $205 \%$, breaking a new record for total exports each year except 2001 (a recession year). During the same period, Mexico's imports have grown by nearly $158 \%$. The U.S. share of Mexico's trade has likewise increased with NAFTA. In 2001, the United States accounted for $88.55 \%$ of Mexico's total exports and $70 \%$ of its total imports. In 2002, the U.S. share of Mexico's total exports increased slightly to $88.96 \%$ and its share of Mexico's total imports decreased to $63.13 \%$. Mexico now represents the second most important U.S. trading partner and is on course to take the top spot from Canada in 2010.

Mexico is vigorously pursuing free trade agreements with other countriesto reap the benefits of trade and to reduce its dependence on the U.S. market. Mexico has a free-trade agreement with the European Union similar in coverage to NAFTA, and also benefits from agreements with Chile, Costa Rica, Uruguay, Bolivia, Colombia, Venezuela, Nicaragua, Israel, the "Northern Triangle" (Guatemala, El Salvador, and Honduras), and the European Free Trade Association (Norway, Switzerland, Iceland, and Liechtenstein). Negotiations to liberalize trade are ongoing with Brazil, Argentina, Panama, and Japan. Mexico's membership in APEC (for which it was president in 2002), its active participation in the creation of the Free Trade Area of the Americas (FTAA), and its pursuit of bilateral investment treaties give further testimony to Mexico's commitment to economic liberalization.

\section{Marketing U.S. Products and Services}

There are a number of factors that should be considered in exporting products to Mexico. This section provides a brief overview of many critical factors that must be considered. American firms that seek to sell their products in the Mexican market can use different approaches to achieve this goal.

\section{Establishing a Business}

For U.S. companies wanting to establish a presence in Mexico, the General Law of Mercantile Organizations (or the Civil Code) regulates the many forms of business entities. The type of business incorporation that a U.S. company or individual chooses is extremely important because it determines the operations they are allowed to perform in Mexico 
and, among other liabilities, the amount of taxes they pay.

Some of the most commonly used types of business forms are the Sociedad Anonima (Corporation), or "S.A.", and the Sociedad Anonima de Capital Variable (Corporation with Variable Capital), or "S.A. de C.V." (the initials come at the end of the company's name). One of the advantages of the latter is that the minimum fixed capital can be changed subsequent to the initial formation.

The Limited Liability Partnership (Sociedad de Responsabilidad Limitada), or "S. de R.L.", is similar to a closed corporation in the United States, and it also has the option of having a variable capital ("S. de R.L. de C.V."). As this is an organization formed by individuals, it can have similar characteristics to a partnership, with the exception of the unlimited liability.

Civil Partnership (Sociedad Civil), or "S.C.", is the most common organization for professional service providers. It has no minimum capital requirements and no limit in the number of partners, but it is taxable in the same way as a corporation.

Civil Association (Asociacion Civil), or "A.C.", is the form that charitable or nonprofit organizations adopt to operate. Many industrial and commercial firms and professional organizations are grouped into this form.

A foreign company may open a branch ("sucursal") in Mexico as an alternative to incorporating. A branch can provide rights and responsibilities similar to a corporation, including tax liability and access to local courts, but requires the approval of the National Foreign Investment Commission.

\section{Distribution / Sales Channels}

- Selling Direct to the End-User: This approach allows both sides to eliminate "the middleman" and reap the benefits of direct contact. Negotiations take less time. There is no distributor mark-up. The U.S. firm can know first-hand the requirements of the client. Many Mexican firms employ English-speaking staff, but it is a good idea for U.S. companies to employ Spanish-speaking sales representatives. One drawback is that U.S. firms must be much more knowledgeable regarding the Mexican commercial environment. There also are cost considerations (e.g., sales representatives based in the United States may have to do extensive travel in Mexico).

\section{- Selling through Distributors in the United} States: Mexican firms generally prefer to deal directly with the manufacturer rather than through U.S. distributors, since this incurs an extra markup. For U.S. firms, however, the advantage of this approach is that the costs of market development and any risks associated with non-payment are borne by the U.S. distributor. It is common for Mexican firms in the northern region to purchase through distributors located on the U.S. side of the border, as this can be cheaper than purchasing through a Mexican distributor.

- Selling through a Mexican Manufacturer: Some Mexican manufacturers sell products manufactured by American firms. Usually, the Mexican manufacturer seeks to complement its product line using this method. American firms that want to use this distribution channel should consider registering their products in Mexico to avoid possible patent infringements.

- Selling through Wholesalers: Some U.S. firms use Mexican wholesalers to distribute their products. Through this channel, U.S. firms can take advantage of the wholesaler's distribution infrastructures. In addition, by using this channel, U.S. firms negotiate with only one party, smoothing the distribution process. However, some industry sectors have few, if any, wholesalers. A wholesaler is an efficient channel for consumer products or business and industrial consumables.

- Selling through Distributors/Retailers: Many U.S. firms use distributors and/or retailers to distribute their products in Mexico. This channel can be used to distribute products in various regions or to distribute to several lines of business. For example, a distributor can be used to sell to the automobile industry, and another 
distributor to sell to the financial sector. This channel is also efficient when distributors are required to carry stocks of the product.

- Selling through Agents: Some U.S. firms sell their products through sales agents. Usually, sales agents are freelancers. However, some Mexican firms are interested in serving as sales agents for American firms. This channel can be efficient for reaching the smaller cities or more remote locations of the country.

\section{Agents / Distributors: Finding a Partner}

Selection of the appropriate agent or distributor requires time and effort. Though there may be many qualified candidates, U.S. firms should use high standards in selecting agents/distributors. Since most Mexican firms are selling into a limited area, U.S. companies should consider appointing representatives in multiple cities to broaden distribution, and rarely, if ever, grant an exclusive, national agreement. It is important to develop a close working relationship with appointed agents/distributors. Providing appropriate training, product support, and timely supply of spare parts is critical to success. There are no indemnity laws to prevent a company from canceling an agent or distributor agreement, but the cancellation clause should include specifics, and this clause should be free of vague language. Sales performance clauses in agent/distributor agreements are permitted and failure to meet established standards can be a reasonable cause for contract cancellation.

Before signing the agent/distributor agreement, make certain that the person understands the terms and conditions and the relationship to be developed. Many relationships are strained because insufficient time is invested in developing a full understanding of what is expected.

The Commercial Service and other organizations, such as the American Chamber of Commerce and U.S. state government offices, maintain lists of Mexican agents/distributors, manufacturers, Mexican government offices, and private sector trade organizations. After identifying a suitable agent/distributor, the U.S. exporter is encouraged to conduct a commercial background check on the Mexican firm, such as offered by the U.S. Commerce Department's International Company Profile (ICP) report.

If the product is new to the market, or if the market is extremely competitive, advertising and other promotional support should be negotiated in detail with your representative. Product and industry knowledge, track record, enthusiasm, and commitment should be weighted heavily. Service and price are extremely important to Mexican buyers. The U.S. exporter should also schedule frequent visits of Mexican personnel to the U.S. companies for training. Other factors to consider include financing, as the commercial and industrial sectors' resources are limited due to high interest rates. Joint venture arrangements should also be investigated to strengthen market penetration. Direct marketing and telemarketing are still evolving as a marketing strategy, but they are gaining in popularity and scope.

\section{Direct Marketing}

American firms making direct sales to companies in Mexico need to be more concerned about following good international trade practices than about Mexican law. The biggest worry for a company selling internationally is making sure they get paid. Many types of payment are commonly used, including letters of credit, pre-payment, documents against payment, open account, and receivable insurance. Mexico is a member of the United Nations' Convention on International Sales of Goods, and U.S. firms are encouraged to become familiar with this treaty since they can request the Mexican importer to honor the provisions of this convention, if appropriate.

Firms doing business from the United States that do not establish a presence in Mexico do not create income tax or other obligations with the Mexican government. If a U.S. firm wants to appoint an intermediary, such as an agent or distributor, the Mexican representative should be limited to doing market research, promotion, solicitation, and negotiations for the sale of products and services. If desired, U.S. firms can grant permission to the local company to execute contracts. In addition, it is common practice for the Mexican representative to provide their Mexican clients with information such 
as pricing, payment terms, etc. Also, the Mexican representative will normally receive payment on behalf of the U.S. firm.

\section{Franchising}

The franchise sector in Mexico has become one of the most successful sectors in Mexico despite the uncertainty of the economy in the global market. Mexico is the 11th leading nation worldwide in franchise development.

In the last five years, franchising in Mexico has grown at $10 \%$ annually. There are over 500 brand names operating in Mexico, of which $40 \%$ are foreign and $60 \%$ are Mexican. In 2002, franchisers had approximately 30,000 points of sale.

Service franchises have shown rapid growth in the last few years and currently account for $24 \%$ of franchise market share. Particularly popular are education and training services, business services, advertising, financial consulting, printing and publishing, temporary job services, health care services, and automotive services.

In an effort to support the establishment and expansion of franchises in Mexico, the Mexican government has signed an agreement with the Overseas Private Investment Corporation (OPIC) to provide financial aid to Mexican individuals interested in U.S. franchises.

There are no barriers to franchisers of any products or services in Mexico.

\section{Advertising / Trade Promotion}

There is a wide range of broadcast and print media available in Mexico. There are approximately 20.7 million homes in Mexico, of which 19.7 million (95\%) have electric power. Around $95 \%$ of homes have at least one radio and $87 \%$ of homes have at least one TV set. Radio has the widest coverage. There are $384 \mathrm{FM}$ and $758 \mathrm{AM}$ radio stations throughout Mexico. Most of the radio stations broadcast 24 hours a day.

There are eight TV networks having national coverage and more than 636 local or regional TV stations. "Televisa" and "Television Azteca" are the largest standard broadcast TV networks. In addition, there are 564 cable TV systems offering services to 3 million subscribers nationwide. The largest cable TV company is Cablevision, owned by Televisa, which has 407,000 subscribers in Mexico City. There also are two Spanish language direct-to-home satellite networks: Multivision and Sky.

According to data provided by the National Chamber of the Publishing Industry, more than 420 newspapers and 1600 magazines are published in Mexico. Many magazines are industry specific. Advertising in Mexican print media is usually more expensive than in the United States. Advertising rates generally approximate those of large international cities.

Advertising on billboards is also common in Mexico. There are more than 100 billboard companies in Mexico offering billboards ranging from plain paper billboards to electronically controlled billboards. According to data provided by Medios Publicitarios Mexicanos, there are over 131 advertising agencies, 40 market research companies, 8 direct mailing companies, 21 sales promotion agencies, and 7 direct marketing agencies.

Successful ad campaigns are generally described as having a local touch, which may include both linguistic and cultural considerations. Exporters may wish to seek assistance from one of the many full-service advertising agencies in Mexico City, many of which are branches of U.S. and other firms.

\section{Product Pricing}

Exporters should look carefully at import duties (taking into account the NAFTA progressive tariff reductions), brokers' fees, transportation costs, and taxes to determine if the product/service can be priced competitively.

The import duty, if applicable, is calculated on the U.S. plant value (FOB price) of the product, plus the inland U.S. freight charges to the border and any other costs listed separately on the invoice and paid by the importer. These can include charges such as export packaging, inland freight cost, and insurance. 
Mexican Customs collects a value-added tax or IVA from the importer on foreign transactions when the merchandise enters Mexico. This IVA is assessed on the cumulative value consisting of the U.S. plant value (FOB price) of the product(s), plus the inland U.S. freight charges, any other costs listed separately on the invoice such as export packing, insurance, plus the duty, if applicable.

The IVA is $10 \%$ for products exported to the "border zone", defined as 20 kilometers from the U.S.-Mexico border. For final shipping points, other than the border zone, a 15\% IVA is charged. The importer will pay other IVA fees for services such as inland Mexico freight, warehousing, and custom brokerage fees, if applicable. The IVA typically is recovered at the point of sale. Sales of real property (real estate) within the border zone are taxed at the $15 \%$ IVA rate. The law considers several exceptions for the payment of the IVA taxes.

On January 1, 2002, a 5\% luxury tax was set on a range of goods and services. In November of 2002, the Mexican Supreme Court declared the tax to be unconstitutional. Consequently, in December of 2002, the Mexican Congress ratified the elimination of the luxury tax.

To avoid dumping practices, the Mexican authorities have set minimum prices for a wide range of imported products. These minimum prices will be taken as the base for calculating any duty or taxes, if applicable, for all products imported under certain Harmonized System CodesKnown as reference pricing, the U.S. Government continues to talk with the Mexican Government about doing away with this system of estimated prices.

\section{Selling to the Government}

American firms, their Mexican agents, distributors, and representatives interested in government procurement should become familiar with some new laws. In addition, U.S. firms may take advantage of electronic means to participate in the bidding process. American firms wanting to learn more about tenders and calls for bids in Mexico can check online at http://www.compranet.com.mx (includes information on on-going tenders, assigned tenders, statistics, and complaints).

\section{IPR Infringement Protection}

The Mexican Institute of Industrial Property is the legal authority charged with administering and protecting intellectual property rights (IPR) in Mexico.

Intellectual property rights are divided into two basic categories: the invention side (patents, utility models, industrial models, industrial drawings, and trade secrets) and the distinctiveness side (trademarks, trade dresses, trade names, slogans, and designation of origin). Consequently, two different laws exit for the protection of intellectual property, the Industrial Property Law (Ley de Propiedad Industrial) and the Federal Copyright Law (Ley Federal del Derecho de Autor).

Although a firm or individual may apply directly, most foreign firms hire local law firms specializing in intellectual property. The U.S. Embassy commercial section will provide a list of such law firms in Mexico on request. More information can be obtained at the websites for the Mexican Institute of Industrial Property (IMPI) and the American Chamber of Commerce (Amcham).

\section{Need for a Local Attorney}

The legal and regulatory requirements in any country affect the way a company does business, and maneuvering through the legal maze in Mexico can present many pitfalls for foreign firms. Since NAFTA was approved, Mexico has been making a concerted effort to bring its laws and regulations into line with the accord's provisions. This has resulted in a measure of legal continuity among the agreement's member nations, but important differences remain.

Many U.S. firms make the mistake of assuming that Mexico's legal framework is very similar to that of the United States and depend on their American legal counsel to advise them on doing business in Mexico. Even with U.S. counsel, the U.S. Embassy recommends that a Mexican attorney, or an American attorney trained in Mexican law, review all legal documents related to the firm's business operations in Mexico, including labor contracts and obligations. Also, all contracts should have firm arbitration clauses. Litigation, as in the United States, is both 
costly and lengthy. Investment regulations can be very important for some U.S. companies wanting to do business in Mexico, since the Foreign Investment Law and NAFTA now allow corporations with up to $100 \%$ foreign equity.

\section{Agribusiness Industry Prospects}

The Agricultural Trade Office (ATO) serves as the U.S. Department of Agriculture's (USDA) marketing arm in Mexico. The ATO's primary mission is to assist in the market development and promotion of U.S. agricultural, fishery, and forestry products in Mexico. In addition to offering U.S. exporters of agricultural products a modern business facility in Mexico City outside of the U.S. Embassy, the ATO in Mexico City is also home to eight "cooperator groups" that promote sales of U.S. food and agricultural products in Mexico from their respective producer groups in the United States. The ATO provides U.S. exporters of food and agricultural products and U.S. agribusiness representatives a variety of export services. These services include the organization of trade shows and export promotion programs, the compilation and distribution of market information and lists of distributors and importers by product, export counseling, export credit assistance, and online information access via Internet.

A second ATO opened in 2002, in Monterrey, Nuevo Leon. Representatives of U.S. agribusinesses are also co-located in that office. The regional ATO offers all the services described above to U.S. exporters and agribusiness representatives who are interested in developing the northern Mexican market for their products.

The best sales opportunities for consumer ready food products, which represent the fastest growing sector for U.S. food and agricultural product exports, are through Mexico's retail sector and hotel and restaurant industry. There are over 2,000 supermarkets throughout Mexico. National retailers invested over US $\$ 1.0$ billion in 2001, and continued to invest and expand into new outlets in 2002.Increasing numbers of retail outlets and the modernization of equipment, particularly the cold chain, all bode well for U.S. exports of consumer ready products.
Exports of U.S. agricultural, fish and forestry products to Mexico decreased $0.02 \%$ in 2002 to almost US $\$ 7.7$ billion, as a result of a sluggish Mexican economy that contracted $0.3 \%$.

American consumer-oriented agricultural product exports to Mexico decreased $0.14 \%$. Products that showed some growth in consumer sales were processed fruits and vegetables $(0.05 \%)$ and fresh, chilled, and frozen red meats $(0.04 \%)$.

\section{Trade Regulations and Standards}

\section{Trade Barriers}

NAFTA came into force on January 1, 1994, Mexico embarked on a progressive, scheduled reduction of tariffs on U.S. and Canadian goods. NAFTA progressively eliminates tariffs and non-tariff barriers to trade in goods, improves access for services trade, establishes rules for investment, strengthens protection of intellectual property rights, and creates a dispute settlement mechanism.

Mexican tariffs on U.S. goods currently are between $0 \%$ and $10 \%$ ad valorem, with an average of $0.1 \%$. At present, more than $80 \%$ of U.S. goods enter Mexico duty-free. Under NAFTA, tariffs on U.S. goods will be phased out over a 10 -year period with a few exceptions on selective products, mostly agricultural commodities, which will be phased out over a 15-year period. On January 1, 2003, the tariff for most agricultural goods was reduced to $0 \%$, with exceptions for sugar, corn, non-fat dry milk, and beans (which takes effect in 2008). Due to this reduction and strong competition from the United States, some producer and campesino groups are pressuring the Mexican government to renegotiate the agricultural chapter of NAFTA. To date the government has resisted this pressure.

Mexico has negotiated free trade agreements with 32 countries, including the European Union, European Free Trade Area, Israel, and 10 countries in Latin America. Mexico is holding free trade discussions with additional Latin American and Asian trading partners, including Brazil, Argentina, Panama, and Japan. The significance of this for U.S. exporters is that many of our strongest international trade competitors enjoy duty-free access to the 
Mexican market equivalent to that provided by NAFTA (if they do not today, they might in the near future).

Mexico also has implemented what are called "Sectoral Promotion Programs" (PROSEC), which reduce MFN tariffs to $0 \%$ or $5 \%$ on a wide range of important inputs needed by Mexico's export manufacturing sector. This program includes some 20 different industry sectors and affects 16,000 tariff line items. Mexican companies must be registered under this program to participate, and it can be difficult to qualify. Again, the significance for U.S. exporters is that manufacturing inputs from competitors in other countries may be able to enter Mexico duty free or pay only a $5 \%$ tariff, which diminishes the relative advantage enjoyed under NAFTA. Another consideration for U.S. exporters is that it may not be necessary for Asian companies to comply with the requirements of NAFTA to sell duty free (or at minimal duty) in Mexico.

Under NAFTA, the import duty is calculated on the U.S. plant value of the product(s) (invoice) plus the inland U.S. freight charges to the border and any other costs listed separately on the invoice and paid by the importer such as export packing. All products imported definitively into Mexico no longer need to pay the Customs processing fee (CPF). Products temporarily imported for processing and re-export may be subject to the CPF since the imports are not considered "definitive".

Mexico has, in addition, a value-added tax (IVA) on most sales transactions, including sales of foreign products. The IVA is $10 \%$ for products staying in the Mexican border region and $15 \%$ for products entering the interior of Mexico. Basic products such as food and drugs (but not processed foods) are exempt from the IVA. The $10 \%$ to $15 \%$ value-added tax is assessed on the cumulative value of the transaction, as listed above, plus the duty. The importer will pay other IVA fees for such services as the inland Mexico freight and warehousing. The IVA typically is recovered at the point of sale. The IVA may be waived for imports by a manufacturing plant registered under an approved Mexican government program (e.g., maquila plant). Some products classified as luxury goods must pay an additional 5 percent IVA.
A special tax on production and services (IEPS) is assessed to the importation of alcoholic beverages, cigarettes, cigars, and non-alcoholic beverages with a sweetener other than cane sugar, among others. This tax may vary from $20 \%$ to $110 \%$, depending on the product.

Where an "arm's length" transaction does not exist between seller and importer, such as in intra-company sales or transfers, Mexico applies valuation rules that are compatible with the Brussels Customs Valuation Code. Goods for which the NAFTA preferential tariff treatment is not requested are valued on a CIF basis.

\section{Standards}

Under Chapter IX of NAFTA, Mexico, the United States, and Canada agreed to provide national treatment in standards related issues. National treatment simply means that imported products must comply with the same requirements as locally manufactured ones. Mexico has also affirmed its WTO (GATT) obligations to adopt international standards whenever possible. The extent to which these international standards are compatible with U.S. standards varies by industry sector. The Mexican government only recognizes as international standards those issued by ISO/IEC. These standards tend to favor European manufacturers. Compliance with international standards does not translate to compliance with Mexican standards. Even if Mexican standards are compatible with those of the United States and Canada, companies must show compliance with mandatory Mexican standards, known as Normas Oficiales Mexicanas (NOM). Several NOMs cover labeling requirements while others cover user safety and other requirements.

Further information concerning Mexican standards and product certification requirements can be obtained from the National Center for Standards and Certification Information, National Institute of Standards and Technology, (telephone 301-975-4040; fax 301-926-1559; e-mail NCSCI@ nist.gov), or online at http://www.export.gov (includes lists of recently proposed and enacted standards in Mexico as well as other market research information). The actual text of most standards can be downloaded 
from the website for the Mexican General Directorate for Standards of the Ministry of the Eonomy.

\section{Labeling Requirements}

The common feature of most labeling requirements is that package labels must carry commercial information in Spanish. If the required information appears in a language other than Spanish, then this information must appear in Spanish in the same font size, format, and clarity as it appears in the other language. Consequently, many of the labels added to packages in the past for the Mexican market are not acceptable. However, placing stickers over information preprinted on a package or label is allowed as long as the resulting label complies with the labeling requirements. Additionally, labels can be applied or modified in Mexico provided that the process complies with Mexico's verification procedures.

A comma must be used as a decimal point in the quantity declaration on packages, as required by NOM-008-SCFI-1993. Imported products using a period as a decimal point are likely to be rejected by Mexican Customs officials. Accredited label verification units exist in Mexico, where companies can obtain an evaluation of their labels prior to export to Mexico for a small fee (usually below US\$100.00).

\section{Import Controls}

Certain sensitive products must obtain an import license for which the difficulty varies according to the nature of the product. Periodically, the Mexican government publishes lists that identify the different items that have a specific import control. Items are identified according to their Harmonized System (HS) code number; therefore, it is important that U.S. exporters have their products correctly classified. American exporters are encouraged to check with Customs brokers as to the accurate classification of their products.

Mexican government agencies requiring import licenses include the Secretariat of Agriculture (SAGARPA) for some leather and fur products, fresh/chilled and frozen meat, and agricultural machinery among others, and the Secretariat of Health (SSA) for medical products and equipment, pharmaceuticals, diagnostic products, toiletries, processed food, and certain chemicals. Food supplements and herbal products are highly regulated in Mexico, unlike in the United States. In some cases only pharmaceutical-like companies may be eligible to import them.

For tax purposes, all Mexican importers must apply and be listed on the "Padron de Importadores", which is maintained by the Secretariat of Finance and Public Credit (Hacienda). In addition, Hacienda maintains special sectoral registries. To be eligible to import more than 400 different items, including agricultural products, textiles, chemicals, electronics, and auto parts, Mexican importers must apply to Hacienda to be listed on these special industry sector registries. Infrequently, U.S. exporters have encountered problems when products are added to the list without notice or importers are summarily dropped from the registry without prior notice or subsequent explanation.

The basic Mexican import document is the "pedimiento de importacion". This document must be accompanied by a commercial invoice (in Spanish); a bill of lading; documents demonstrating guarantee of payment of additional duties for undervalued goods, if applicable; and documents demonstrating compliance with Mexican product safety and performance regulations, if applicable. The import documentation may be prepared and submitted by a licensed Mexican Customs broker or by an importer with sufficient experience in completing the documents.

Products qualifying as North American must use the NAFTA Certificate of Origin to receive preferential treatment. This must be issued by the exporter and does not have to be validated or formalized.

Unless the importer is accredited to act as a Mexican Customs broker, the participation of a professional Customs broker is necessary to ensure compliance with Mexico's Customs regulations. Mexican Customs law is very strict regarding proper submission and preparation of Customs documentation. Errors in paperwork can result in fines and even confiscation of merchandise as 
contraband. Exporters are advised to ensure that Mexican clients employ competent, reputable Mexican importers or Customs brokers. Because Customs brokers are subject to sanctions if they violate Customs laws, some have been very restrictive in their interpretation of Mexican regulations and standards.

\section{Export Controls}

Mexico is not subject to any special U.S. export control regimes, and is designated as a Category I country (the least restrictive) for receipt of U.S. high technology products.

\section{Investment Climate in Brief}

- American and Canadian investors generally receive national and most-favored-nation treatment in setting up operations or acquiring firms.

- Mexico is open to foreign direct investment (FDI) in most economic sectors and is consistently one of the largest recipients of FDI among emerging markets. The United States is the largest source of FDI in Mexico by far.

- The Mexican government has had some success in simplifying the process of investing in Mexico. The website for the Secretariat of Economy (SECON) offers "one-stop shopping" for online regulatory compliance across several categories. The SECON website also contains the link to the Rapid Business Start-Up System (SARE), which reduces the number of government formalities required to open a low-risk business and reduces the time required.

- Investment restrictions still prohibit foreigners from acquiring title to residential real estate within 50 kilometers of the nation's coast and 100 kilometers of the borders. Nonetheless, foreigners may acquire the effective use of residential property in the residential zones via a trust arrangement through a Mexican bank.

- The Mexican Foreign Investment Law identifies 704 activities, 606 of which are open for $100 \%$ FDI stakes, 35 where foreigners may only invest $49 \%$, and 37 that require Foreign
Investment National Commission approval for a $100 \%$ stake (16 reserved for Mexican nationals and 10 reserved for the Mexican state).

- Mexico has open conversion and transfer policies as a result of its membership in NAFTA and the Organization for Economic Cooperation and Development (OECD).

- Under NAFTA, Mexico may not expropriate property, except for a public purpose and on a non-discriminatory basis.

- The Mexican government has a good record of handling investment disputes. Despite the large amount of U.S. investment in Mexico, the Embassy is aware of only ten unresolved cases.

- The 1993 Foreign Investment Law eliminates such restrictions as export requirements (except for maquiladora industries), capital controls, and domestic content percentages, which are prohibited under NAFTA. Foreign investors already in Mexico at the time that law became effective could apply for cancellation of prior commitments.

- Foreign and domestic private entities are permitted to establish and own business enterprises and engage in all forms of remunerative activity in Mexico. For more information, see the Online Guide to Mexico website.

- Secured interests in property are recognized and enforced.

- The Federal Commission on Regulatory Improvement and SECON are the entities charged with lessening the regulatory burden on business. The Mexican government has made some progress in the last several years in this regard. New government rules and regulations must meet the following criteria: there must be a clear justification for government involvement; regulations must be maintained or issued only on evidence that their potential benefits exceed their potential costs; there must not exist regulatory alternatives that would cost less; regulations must minimize the negative impact they have on businesses, especially small and medium firms; 
and regulations must be backed by sufficient budgetary and administrative resources to ensure their effective administration and enforcement.

- The Mexican government has eliminated most direct tax incentives. The only significant federal tax incentive is accelerated depreciation.

- Nacional Financiera (a state-owned development bank) provides loans to companies in priority development areas and industries. It is active in promoting joint Mexican-foreign ventures for the production of capital goods.

- Most foreign investors operate in Mexico through corporations (Sociedades Anonimas de Capital Variable). Foreign-owned corporations are subject to the same laws as local companies and any special regulations governing foreign investment.

- The Mexican government recognizes that corruption is a severe problem and has taken steps to combat it. The government has enacted strict laws attacking corruption and bribery, with average penalties of five to ten years in prison.

- Mexico has bilateral investment protection agreements with 15 countries: 10 of the 15 European Union Countries (Austria, Denmark, Finland, France, Germany, Greece, the Netherlands, Portugal, Spain, and Sweden), as well as Argentina, Cuba, South Korea, Switzerland, and Uruguay. The United States and Mexico have a bilateral tax treaty to avoid double taxation and to prevent tax evasion and a tax information exchange agreement to assist the two countries in enforcing their tax laws.

- In June of 2003, Mexico and the U.S. Overseas Private Investment Corporation (OPIC) signed an agreement that will enable OPIC to offer all its programs and services in Mexico. The agreement must be ratified by the Mexican Senate to become effective.

- Mexico has two duty-free ports: Puerto Mexico and Salina Cruz.

\section{Business Customs}

\section{Travel Advisory and Visas}

There is a single visa form for tourist and business visitors, valid for 30 days on entry with no fee. This form is normally distributed on all arriving aircraft. Business visitors must be careful not to enter as a tourist if their reason for visiting includes any of the following activities: business meetings, trade events, consulting, technical support, or marketing.

Contracts and other business agreements entered into while a U.S. visitor to Mexico is traveling on tourist rather than on business status are not legal, and there have been rare instances of immigration authorities detaining visitors doing business while on tourist status, resulting in fines up to US $\$ 2,000$. Immigration officials also have the authority to bar such travelers from obtaining visas in the future.

If a U.S. businessman wants to reside in Mexico and work on a more permanent basis, it is necessary to obtain an FM-3 immigration form. This form may be obtained with validity up to one year, renewable up to a total of five years. The cost as of July 6, 2003, was about US\$165 at current exchange rate. A NAFTA-FMN entry permit can be converted to an FM-3 visa in country at the nearest immigration office.

The Mexican immigration authority has reinstated a visitor's fee that was dropped over 30 years ago. Mexico's Congress authorized the fee to be collected from foreign visitors with the stated goal of computerizing visitor entry and expanding tourist services. The fee is set at 195 Mexican pesos, currently about $\$ 20$ U.S. dollars.

For further information please contact: the Mexican Embassy, Consulate, or visit the Mexican Ministry of Tourism (SECTUR) website.

Street crime is common, especially in urban areas. If accosted, DO NOT RESIST, as resistance is the number one reason that otherwise non-violent crime becomes violent. Do not leave your pockets unprotected or purses open, any more than you would in any large city. Avoid wearing expensive watches and jewelry and carrying large sums of cash, your 
passport, and multiple credit cards. Leave these in a hotel safe, not in your room. Make sure you know the PIN numbers for any credit or debit/cash cards you carry, and do not carry cards for which you do not have a PIN. If necessary, write any PIN numbers on a piece of paper and carry it with you separate from your wallet.

The U.S. Embassy advises its personnel not to travel on Mexican highways after dark and not to take roving taxicabs in Mexico City. These taxis are frequently used to apprehend visitors and hold them until sufficient money is extracted using their credit cards in automatic teller machines (hence the importance of knowing all PIN numbers). Use only taxis called by your hotel, place of business, or from "sitios" (cab stands). Exercise caution walking in areas frequented by tourists and shoppers. Do not walk alone at night, and do not get involved in conversations with strangers, which a favorite tactic of con artists and thieves.

\section{Business Infrastructure}

Business and social customs vary widely in Mexico. It is best to be observant and flexible, and to take cues from the Mexicans around you.

The length of the workday varies depending on the region of the country and the type of organization. In Mexico City, company work hours are 9:00 a.m. to 6:00 p.m. or 7:00 p.m., with a long lunch beginning at 2:00 p.m. or later. In the north, the workday may begin and end earlier with lunch at 1:00 p.m. Federal government offices in Mexico City traditionally operate from 10:00 a.m. to 9:00 p.m., with a lunch break from 2:00 p.m. or 3:00 p.m. until 5:00 p.m. or 6:00 p.m. Beginning April 1, 1999, the federal government issued new instructions for offices to operate between the hours of 8:00 a.m. and 6:00 p.m., with flexible arrival and departure times for employees. In practice, however, many offices continue to operate according to the traditional schedule.

Business cards are used extensively. Come with a large supply.

Mexicans make extensive use of professional titles (doctor, profesor, licenciado, ingeniero). It is courteous to address them by their titles. Along with this formality is an emphasis on appearances, which means avoid casual dress.

When meeting in a group, it is customary to shake hands with all on arrival and departure. Special respect may be given to older members. A single air-kiss on the cheek is expected for all women present, although this is not necessary in the first meeting.

Business meals are important, especially lunch. Mexicans are accustomed to smoking and drinking freely at business meals. Participation in social activities is very important to succeed in the Mexican business world.

Patience is the key to doing business in Mexico. Business meetings in Mexico will often take longer than they would in the United States. Etiquette often includes much small talk before getting into business. Ask about your counterpart's hometown; university; and/or personal interests, including sports; and family. On the other hand, some U.S. executives have found their Mexican counterparts to be initially brusque and perhaps wary of a U.S. company's sincerity or intentions. Again, it is difficult to make generalities.

In Mexico, "yes" does not always mean yes. Mexican social etiquette makes it difficult to say no. In conversation, Mexicans emphasize tactful and indirect phrasing, and may be more effusive than Americans with praise and emotional expressions. Do not be overly aggressive while negotiating; it is considered rude.

The concept of time is flexible in Mexico. Guests to social events (except in the case of cities in the North) can arrive an hour late. However, punctuality is observed for most government appointments and social functions.

Although the presence of women in business is increasing, business in Mexico remains male-oriented. However, this need not be considered an obstacle to the participation of women in Mexico 


\section{Useful Web Sites}

\section{MEXICO:}

- Mexico Connect

http://mexico-connect.com/pages/Business_-

_Economy/Agribusiness

- Mexican Institute of Industrial Property

http://banapanet.impi.gob.mx/Contador/ index.html

- American Chamber of Commerce - Mexico

http://www.amchamcom.mx

\section{UNITED STATES:}

- USDA Foreign Agricultural Service

http://www.fas.usda.gov

- US Export Programs Guide http://infoserv2.ita.doc.gov/ticwebsite/tic.nsf/ AF34FA880278BDD5825690D00656C6F/ F69FDCF72B7713B58525691900746F18?Open

Document

- Internet Guide to Trade Leads http://infoserv2.ita.doc/gov/ticwebsite/tic.nsf/ $504 \mathrm{ca} 249 \mathrm{c} 786 \mathrm{e} 20 \mathrm{f} 85256284006 \mathrm{da} 7 \mathrm{ab} /$ ef7db94aef24919885266470049c1cd?OpenDocu ment

- US Trade Finance Resources http://infoserv2.ita.doc.gov/ticwebsite/tic.nsf/ AF34FA880278BDD5825690D00656C6F/ F69FDCF72B7713B58525691900746F18?Open Document

- Basic Guide to Exporting http://www.unzco.com/basicguide/index.html

\section{HEMISPHERIC:}

- Hemispheric Guide on Customs Procedures http://alca-ftaa.iadb.org/hgcp_eng.htm

- Hemispheric Trade and Tariff Database http://alca-ftaa.iadb.org/eng/ngmadb_e.htm 